Available online at : http://journal.unj.ac.id/unj/index.php/gjik

Gladi : Jurnal Ilmu Keolahragaan 12 (01) 2021, 73- 79

Permalink/DOI: https://doi.org/10.21009/GJIK.121.10

\title{
EVALUATION OF THE EXTRACULICULAR DEVELOPMENT PROGRAM OF VOLYBALL IN JUNIOR HIGH SCHOOL
}

\author{
Siswantoro $^{1}$, Moch. Asmawi ${ }^{1}$, James Tangkudung ${ }^{1}$ \\ ${ }^{1}$ Physical Education, Postgraduate Universitas Negeri Jakarta, \\ Universitas Negeri Jakarta Complex Jl. Rawamangun Muka East Jakarta Indonesia13220 \\ Correspondiing author. Email : galangsiswantoro1971@gmail.com
}

\begin{abstract}
The purpose of this study was to find out the volleyball extracurricular development program in Tambun Utara sub-district using the CIPP eva-luation model (Context, Input, Process and Product). By using the CIPP method, which was presented by Daniel L. Stuflebeam, it is an evaluation of the Context discussion on the background of the program and the purpose of the coaching program. Input Evaluation is a discussion of the acceptance of athletes, coaches, funds, facilities and infrastructure. Process Evaluation, discussion on the implementation of training, consumption / nutrition, coordination and communication programs. Product evaluation, which is about the results of the guided program achievement which is obtained in the volleyball extracurricular program development. The results of this study were obtained from the results of interviews, observations and documentation studies obtained by the researchers that the volleyball extracurricular training program in Tambun North District Public Middle School had carried out the processes and procedures of sports achievement development programs in general. However, the implementation is constrained by funding, training facilities and infrastructure as well as other facilities that can support the training program. The importance of communication and coordination of sports stakeholders has not run as expected in seeking donors both local and private government.
\end{abstract}

Keywords: Evaluation, Guidance Program, Extrakurikuler Volley Ball . 


\section{Gladi Jurnal Ilmu Keolahragaan, 12 (01), March- 74}

\section{Siswantoro, Moch. Asmawi, James Tangkudung}

\section{INTRODUCTION}

Education itself has many different meanings, but its aims and objectives are still focused on improving the quality of human resources. In the National Education System Law No. 20 of 2003 states that "Education is a conscious effort and plans to create an atmosphere of learning and the learning process so that students actively develop their potential to have religious spiritual strength, self-control, personality, intelligence, noble morals and skills needed by themselves, the community, nation and state."

Physical education, sports and health are media to encourage physical growth, psychological development, motor skills, knowledge and reasoning, appreciation of values (attitude-mental-emotionalsportsmanship-spiritual-social), as well as habituation to a healthy lifestyle which leads to stimulating balanced growth and development of physical and psychological qualities. To maintain and improve the quality of one's health, it is necessary to do physical and psychological activities. Sports is a physical activity carried out by a person to meet both physical and spiritual needs (Saefulloh, 2014).

Sports are physical activities carried out by people in the form of games, martial arts and other forms of motion whose purpose is fun or hobbies to maintain fitness, physical health and competition / competition to be the best or champion. Through sports activities, everyone will live healthier and more productive, and of course it is hoped that in a healthy mind, there will be a desire to develop a strong physique, namely by actively exercising.

Sports activities in the community have increased, sport is a necessity for the community, to maintain and improve physical condition in order to stay enthusiastic in carrying out daily activities. Physical education, sports, and health can be used as tools to achieve educational goals.

Through sports activities and games that contain a lot of positive values in them, it is hoped that it can help students develop cognitive and effective abilities, not only psychomotor abilities. So complex the goals of Physical Education, not only in psychomotor abilities, cognitive and affective abilities also cannot be separated from these goals. However, reality sometimes does not match expectations, goals that have been arranged neatly and systematically are still difficult to achieve. Less optimal physical education learning in schools can be one of the causes. Based on teaching experience, meetings that are only once a week make it difficult to achieve these learning objectives.

Achievement sports cannot develop on their own so that it requires a synergy of all 
Gladi Jurnal Ilmu Keolahragaan, 12 (01), March- 75

Siswantoro, Moch. Asmawi, James Tangkudung

parties, in order to ensure development sustainable exercise. The weakness of sustainable sports achievement coaching is very much at odds with the demands of sporting achievement will only succeed in adhering to the consistent, sustainable and sustainable principles of long-term sports achievement coaching. As often argued by experts, that is sports coaching achievement must start from an early age until reaching peak performance, that is takes place through a continuous coaching process for 10-12 years, or at least 10,000 hours of training, therefore the implementation of performance sports coaching emphasizes process rather than results (Rusli Lutan, 2013).

In accordance with the mandate of Law No.3 of 2005 concerning the National Sports System, there is a sub-system of sports activities, namely educational sports, recreational sports and achievement sports. These three subsystems are interrelated and mutually supportive.

The sports education sub-system is implemented as part of the curriculum of educational institutions with a mission to achieve comprehensive educational goals. The goal is from the perspective of physical, cognitive abilities and affective development (Rusli Lutan, 2013).

National sports aim to maintain and improve health and fitness, achievement, human quality, instilling moral values and noble morals, sportsmanship, discipline, strengthening and fostering national unity and integrity, strengthening resilience

nationwide, as well as uplifting the dignity and honor of the nation.

Nowadays, besides academic achievement, achievement in sports is also a parameter, the strength and progress of a school that is assessed by the community, the Education Office as well as the Regional Government. Each school can display and demonstrate its strength by displaying

the best achievements in regional and national multi-event sports such as the National Student Sports Olympiad (O2SN), the National Student Sports Week.

The participation of State Junior High Schools in North Tambun Subdistrict in multi events or championships at the sub-district level as well as at the district level as well as open tournaments in several schools in the Bekasi regency and municipal environment allows him to conduct achievement coaching to prepare volleyball players to excel. Because in principle, when a player is selected and enters a training camp in volleyball extracurricular activities, intensive and wellprogrammed training is aimed at achieving achievements in the Regional Student Sports Week (Popda). 
Gladi Jurnal Ilmu Keolahragaan, 12 (01), March- 76

Siswantoro, Moch. Asmawi, James Tangkudung

In a championship or multi event, it is a parameter for players to see their achievement at the student level. So that until now, the development of achievements in the sport of volleyball is the most common achievement coaching in extracurricular sports at the school level. Junior High School (SMP) is a formal education level under the Ministry of Education and Culture, which is now the Ministry of Primary and Secondary Education, which is responsible for the implementation of education in Indonesia. Where the government compiles a curriculum for all subjects including sports subjects, namely Physical Education, which is the main subject which is allocated 2 hours of lessons in one week. So that it is felt that there is less time needed by students to take assessors' lessons.

State Junior High School in North Tambun District, Bekasi Regency is one of the State Junior High Schools in North Tambun District in Bekasi Regency, which opens volleyball coaching through volleyball extracurricular activities. State Junior High Schools in North Tambun Subdistrict which were representatives in this study were SMP Negeri 2, 3 and 5 Tambun Utara.

One of the first State Junior High Schools in volleyball extracurricular coaching, namely Junior High School 2 North Tambun starting in 2011 always participates in events organized by the Education Office and the Youth and Sports Service, open tournaments organized by public and private schools in regencies and municipalities. Bekasi. They are required to learn as usual by participating in learning activities on the same day and time as other students who do not participate in volleyball extracurricular activities because volleyball extracurricular activities are held outside of class hours.

Even though every year he participates in the events as mentioned above, the volleyball extracurricular achievements of Junior High School 2 North Tambun have not achieved the expected results. The only achievement that was achieved was Champion 4 in the men's volleyball open national level tournament between junior high schools to win the Bekasi Mayor trophy .Moving on from the explanations and empirical data obtained in the field, researchers are interested in raising research on the implementation of the volleyball extracurricular training program.

Based on the record of achievements obtained from volleyball extracurricular activities at Junior High School in North Tambun District, Bekasi Regency, it has attracted researchers to conduct research through empirical scientific studies. To provide a volleyball extracurricular training program that is more precise and is expected to increase the achievement of volleyball extracurricular activities in State Junior High 
Schools $t$ as well as an example and model of extracurricular training programs that can be used as guidelines or references for junior high schools in Bekasi Regency in particular.

\section{METHOD}

The implementation of this research uses a qualitative descriptive method or approach, because the aim is to describe and describe what it is about a certain variable, symptom, state, or social phenomenon. In this case, in order to analyze the data obtained in depth and thoroughly, with the hope that it can be known to what extent the volleyball extracurricular coaching program in North Tambun sub-district is running well and achieving. The design of a program evaluation is a plan that shows when the evaluation will be carried out, and from whom the information or data will be collected, this design is made to ensure that the evaluation will be carried out according to an orderly organization and according to good evaluation rules.

\section{RESULT AND DISCUSSION}

The results of this study are expected to provide benefits both

theoretically and practically for all those who need it

reference / study source, and can also be used as a scientific reference

relating to evaluation studies. In detail, the usefulness of this research is between others, namely:
1) As information and input for Junior High School 2 North Tambun and other junior high schools both public and private to foster students in sports achievement coaching programs.

2) To evaluate the implementation of the selection of participants and trainers, facilities and infrastructure, as well as funding support for the Volleyball Extracurricular activity program at State Junior High Schools in north tambun

3) To evaluate the success of the Volleyball Extracurricular activity program at State Junior High Schools in North Tambun one of the models for the achievement development system in public schools.

4) As input or suggestions to; a). Bekasi District Education Office, b). Administrators of Private School Education Foundations, c). Management of KONI Province, City and District of West Java, d) Bekasi District's Department of Youth and Sports. And can be used as a guide in improving and evaluating the implementation of extracurricular coaching programs, especially volleyball.

\section{CONCLUSION}

Volleyball extracurricular coaching program is one of the programs planned to achieve the desired achievements. Junior High Schools (SMP) Negeri 2,3, and 5 Tambun Utara are schools that accommodate highachieving student athletes in the form of a volleyball special class achievement development model. So that the 
Gladi Jurnal Ilmu Keolahragaan, 12 (01), March- 78

Siswantoro, Moch. Asmawi, James Tangkudung

implementation of fostering achievement both academically and non-academically, namely sports become the main priority of education can be carried out in a balanced manner.

The aim of the volleyball extracurricular coaching program continuously and continuously is to foster talented and accomplished athletes in an effort to achieve peak achievement and achieve general education. In addition, it supports local government programs in terms of increasing the sports achievements of Bekasi Regency as a regional asset to be able to make a presentation on the name of Bekasi Regency in the field of sports both at the regional, provincial, national and international levels.

The obstacle that is one of the obstacles in the implementation of the volleyball extracurricular coaching program, namely the limited facilities, both facilities and infrastructure in schools to support training activities for all athletes assisted by students of SMPN 2,3, and 5 Tambun Utara, Bekasi Regency, is a serious concern of all parties, both local governments. , related agencies, and sports stakeholders to support the smooth implementation of training programs and participating in competitions or championships.

The most important thing is the funding support or budget for the performance development program for special sports classes, which is still minimal, because they still rely on school operational funds and donations from parents of students who are included in special sports classes. So it needs support from the local government and the private sector to be able to help in terms of funding in the implementation of training programs and competitions / championships. With the implementation of the program evaluation, it is hoped that it can reduce any constraints that exist in the implementation of the special sports class achievement development program and can be minimized gradually, these problems and obstacles can be resolved

The sports coaching program is one of the programs planned to achieve the desired achievements both at the student level and at the student or general level. Volleyball is one of the most popular sports and is in demand by students at elementary, junior high and high school levels. State Junior High School (SMPN) which is located in North Tambun District are schools that have extracurricular activities for Volleyball as one of the activities outside of class hours to channel talents and skills in the field of sports, both recognition as well as development towards sports achievement. So that the implementation of coaching achievements both academically and non-academically in junior high schools in the form of volleyball extracurricular activities becomes one of the development of students' talents and potential towards sports achievement at the golden age in coaching, namely the student and student levels. 
Gladi Jurnal Ilmu Keolahragaan, 12 (01), March- 79

Siswantoro, Moch. Asmawi, James Tangkudung

The aim of the volleyball extracurricular coaching program at SMP Negeri 2,3 and 5 North Tambun, Bekasi Regency is carried out in stages, sustainably and continuously to foster and develop students' talents, interests and skills in the volleyball game branch. In addition, to support local government programs through the education office in accordance with the Law on the National Education System, including as a vehicle for guiding and enhancing the talents, skills and potential of students in giftedness in the field of sports. Through the National School Sports Olympiad (O2SN) at the SD, SMP and SMA levels, championships or competitions have been held at the sub-district, city / regency, provincial and national levels. Including the Volleyball sport which is also competed in the multi event.

Therefore, the need for training in sports in schools as extracurricular activities to develop talents and skills for students who are interested and have talent in sports. Also supports the local government of Bekasi Regency in preparing athletes who will be prepared for events or championships that represent regions such as the West Java Regional Sports Week

\section{REFERENCES}

Anas Sudijono, Pengantar Evaluasi Pendidikan, Jakarta: PT. Raja Grafindo Persada, 2007.
Asisten Deputi Penerapan Iptek Olahraga, Deputi Peningkatan Prestasi Olahraga Kemenpora, Bunga Rampai Hasil Penelitian Pembinaan Olahraga, Jakarta: Kemenpora RI, 2009.

Asisten Deputi Penerapan Iptek Olahraga, Deputi Peningkatan Prestasi Olahraga Kemenpora, Jurnal Iptek Olahraga Volume 15, Nomor 2, Mei-Agustus 2013, Jakarta: Kemenpora RI, 2013.

Billy Tunas, Materi Seminar Penelitian Sistems/Program Evaluation Models,

Daryanto, Evaluasi pendidikan, Jakarta: PT. Rieneka Cipta, 2012.

Deputi Penerapan Iptek Olahraga, Pedoman Pengelolaan Pusat Pembinaan dan Latihan Olahraga Pelajar (PPLP), Jakarta: Deputi Bidang Peningkatan Prestasi dan IPTEK Olahraga KEMENEGPORA, 2006.

Djaali dan Pudji Mujiono, Pengukurandalam Bidang Pendidikan, Jakarta:Grassindo, 2008. Jakarta: 2013.

Peraturan Pemerintah Republik Indonesia Nomor 16 Tahun 2007, tentang Penyelenggaraan Keolahraga, Jakarta:

Kementerian Pemuda dan Olahraga, 2011. Rusli Lutan, Pedoman Perencanaan Pembinaan Olahraga, Bandung: PT. Remaja Rosdakarya, 2013.

Sugiyono, Memahami Penelitian Kualitatif, Bandung: CV. Alfabeta, 2005. 
